\title{
Ubiquitin Carboxyl-Terminal Hydrolase 13
}

National Cancer Institute

\section{Source}

National Cancer Institute. Ubiquitin Carboxyl-Terminal Hydrolase 13. NCI Thesaurus.

Code C115006.

Ubiquitin carboxyl-terminal hydrolase 13 ( $863 \mathrm{aa}, \sim 97 \mathrm{kDa}$ ) is encoded by the human USP13 gene. This protein is involved in protein deubiquitination. 